\title{
Commentary
}

\section{Food company sponsorship of nutrition research and professional activities: a conflict of interest?}

\author{
Marion Nestle* \\ Department of Nutrition and Food Studies, New York University, 35 W. 4th Street, 10th Floor, New York, NY \\ 10012-1172, USA
}

\section{Introduction}

The potential for conflicts of interest when corporations establish financial relationships with academic researchers, teachers, and practitioners is under increasing scrutiny, mainly focused on sponsorship by cigarette and pharmaceutical companies. Investigators of sponsorship effects have shown that recipients of grants from such companies tend to publish research results, give advice, and write prescriptions in a way that is more strongly favourable to the sponsors' products than might be expected from a more objective review of the evidence $^{1-3}$. Corporate financial support does not necessarily cause recipients to bias their results, opinions, or actions ${ }^{4}$, but because it raises questions of 'guilt by association', some medical commentators have called for an end to corporate sponsorship 5 , or for new policies to help recipients manage the conflicts of interest that inevitably arise from such relationships ${ }^{6}$.

Although sponsorship by food companies is ubiquitous among academics and practitioners in the fields of nutrition, food, and agriculture, our community has paid scant attention to the conflicts of interest that might arise from this. Like drug and tobacco companies, food companies often sponsor academic work (and in fact many drug and tobacco companies own food companies). They fund departments, research institutes, and investigators; they support meetings, conferences, journals, and lectures; and they freely distribute products, product samples, and teaching materials. Many individuals and organisations depend on such support, and therefore actively seek it. At issue are the consequences of such activities - genuine or perceived - for the credibility of research results and dietary advice.

Financial relationships among food companies and nutrition professionals are not a new phenomenon. A survey in the United States in the mid 1970s identified frequent payments by food companies to nutrition and agriculture faculties for consulting services, lectures, membership on advisory boards, and representation at congressional hearings ${ }^{7}$. More recently, a British study reported that 158 out of 246 members of national committees on nutrition and food policy consult for or receive funding from food companies ${ }^{8}$. Such relationships are so pervasive that it is virtually impossible for nutrition academics not to be recipients of food industry largesse in one way or another. As with sponsorship by tobacco or drug companies, such connections cannot help but raise questions about the ability of nutrition experts to provide independent opinions on matters of diet and public health.

I often hear nutrition colleagues state that the only way to improve the dietary intake of populations is to engage in partnerships and alliances with companies to produce more nutritious food ${ }^{9}$. Although alliances do not necessarily imply an endorsement of the partner's products, they may well give the appearance of doing so. As shown by research on the practices of the tobacco industry, for example, co-opting academic experts is a deliberate corporate strategy to neutralise criticism and promote the sale of products $^{1}$. Indeed, a classic manual on corporate strategies advises companies who want to work with academics to employ a 'modicum of finesse' such that the recruited experts do not recognise their loss of objectivity ${ }^{10}$. The success of this approach is indicated by the outraged reactions of most academics of my acquaintance to any suggestion that food company sponsorship might influence their interpretation of research results or opinions. The possibility that it might do so, however, deserves attention not only by analogy to the documented effects of sponsorship by cigarette and pharmaceutical companies, but also because sponsorship by food corporations is so common among nutrition professionals.

In this commentary, I present a few selected examples of situations in the USA in which food company alliances with nutrition academics and practitioners raise questions of conflicts of interest ${ }^{11}$. These examples describe food company support of nutrition journals and conferences, research investigations, and alliances with professional 
associations. They illustrate the need to consider whether nutrition professionals should apply safeguards similar to those proposed for cigarette and pharmaceutical companies when embarking on financial relationships with food companies.

\section{Sponsorship of professional journals and conferences}

Nutrition journals accept and seek corporate sponsorship to help defray the costs of publication. In 2000, the Journal of Nutrition Education listed eight 'corporate patron friends' and four 'corporate sustaining friends...who make an annual financial contribution to support the goals of the society and its journal'. In 2001, the more research-oriented Journal of Nutrition listed 11 food and drug companies as sustaining associates of its parent society, and the American Journal of Clinical Nutrition listed 28 such companies. The sponsors include companies such as Coca-Cola, Gerber, Nestlé/Carnation, Monsanto, Procter \& Gamble, Roche Vitamins, Slim-Fast Foods, and The Sugar Association, as well as others that make infant formula, nutritional supplements, functional foods, diet products, sugar-sweetened breakfast cereals, and genetically modified crops - all with nutritional attributes currently under active debate.

Companies also advertise in journals. The New England Journal of Medicine and The Journal of the American Medical Association, which publish the 'hottest' of nutrition research, each receive around \$20 million annually from drug company advertising, leading critics to charge that they 'are beholden to drug makers for their economic viability', The Journal of the American Dietetic Association reported \$3 million in advertising in $1999^{13}$, mainly from food and supplement companies. To avoid suggestions that advertisers might influence the content of what gets published, journals sensitive to the issue deliberately attempt - but not always successfully to isolate their editorial functions from interference from the business side of the publication ${ }^{14,15}$.

Food companies also support the publication of papers from sponsored conferences as supplements to nutrition journals. In 2000, for example, companies such as Wyeth Nutritionals, Bristol-Myers Squibb, Mead Johnson, and the International Nut Council helped support publication of supplements to the American Journal of Clinical Nutrition. Such supplements tend to highlight the benefits of particular foods or diets in which the sponsors have some interest. This journal places the letter ' $s$ ' on supplement page numbers, suggesting to knowledgeable readers that the sponsored articles may not have been subjected to the usual rigors of peer-review.

Sponsorship of professional meetings can generate substantial revenue. The American Dietetic Association, for example, reported income of nearly $\$ 900000$ from its 1998 annual meeting ${ }^{13}$. Thus, nutrition societies may actively seek corporate sponsorship, and companies willingly comply. Food, beverage, and supplement companies buy space at exhibits, place advertisements in programme books, underwrite coffee breaks, meals, and receptions, sponsor research awards and student prizes, and provide bags, pens, and other meeting souvenirs. In return, they receive thanks in programme books and get meeting participants to accept items with corporate logos - both of which are forms of advertising. In the USA, the annual meeting of the American Society for Nutritional Science features a Kellogg-sponsored breakfast meeting for heads of university nutrition departments, and research sessions sponsored by such entities as the Dairy Council and the National Cattlemen's Beef Association. The American Dietetic Association acknowledges session sponsorship in its 2000 annual meeting from more than 40 food companies and trade associations, nearly all with commercial interests in the topic under discussion. The Mars company, for example, sponsored a session on phytochemicals in chocolate, Slim-Fast on obesity prevention and treatment, and Gatorade (Quaker Oats) on ergogenic aids in athletes. At this meeting, I participated in a debate on food biotechnology at a session sponsored by Monsanto, and I gave a talk on healthful diets at a session sponsored by the California Avocado Commission (see disclosure statement below).

Does sponsorship influence the content of conference sessions? In my experience, speakers at sponsored sessions tend to be offended by this question. Sponsorship is so prevalent and so financially beneficial that hardly anyone can imagine that it might compromise research or opinion. Studies of pharmaceutical industry practices show that physicians who accept travel funds, meals, or gifts, or who attend sponsored conferences are more likely to write prescriptions for the sponsor's medications ${ }^{16}$. One investigative report reveals the deliberate nature of this strategy by vitamin companies. It describes how a vitamin manufacturer used a medical conference to generate interest in vitamins as agents of health, and notes that the company's influence on conference content was largely invisible, mainly because critics of the products had been excluded from the debate $^{17}$. Although sponsorship of journals and conferences may not directly influence editorial content or the opinions of conference speakers, it may well do so in more subtle ways or give the appearance of doing so.

\section{Research studies}

Whether industry sponsorship influences research results and the opinions of investigators demands careful consideration, not least because the practice is so common. A 1996 survey found nearly 30\% of university faculties to be accepting industry funding ${ }^{18}$. Another survey found $34 \%$ of the primary authors of nearly 800 
papers in molecular biology and medicine to be involved in patents, to serve on advisory committees, or to hold shares in companies that might benefit from the research ${ }^{19}$. Some self-selection is involved; investigators who support the use of drug or tobacco products are more likely to have financial relationships with such companies than neutral or critical authors ${ }^{20}$. Drug and tobacco company sponsorship is strongly associated with research results that minimise the negative health effects of these products ${ }^{2,21}$, and economic analyses of the use of pharmaceuticals also are more likely to demonstrate financial benefits to society from use of the sponsor's products ${ }^{22}$. Such studies do not suggest that industry-sponsored research is always biased, just that there is a higher probability that it will draw favourable conclusions ${ }^{23}$.

As discussed below, many commentators assert that disclosure of sponsorship is the first step in controlling its influence. One notable exception is the British journal Nature. Its editor dismisses concerns about sponsorship in the 'stubborn belief that research as we publish it is indeed research, not business' ${ }^{24}$. This view may explain why the journal was 'pleased to acknowledge' the financial support of The Roche Group - a company that makes a popular drug used in obesity treatment - for a section containing six scientific papers on this condi$\operatorname{tion}^{25}$. The final article concluded that drugs have a useful place in obesity treatment, and one of its authors was employed by Millennium Pharmaceuticals, a Roche partner in obesity drug development ${ }^{26}$. Overall, the presentation of this collection of papers raised questions as to whether it constituted science or advertising.

Similar concerns apply to sponsorship by companies that make food and beverage products or dietary supplements. Appendix A lists some conclusions of research studies sponsored by such companies. Although this list is a selected convenience sample, I found it difficult to find studies that did not come to conclusions favouring the sponsor's commercial interest. Indeed, it seems counter-intuitive to think that companies would sponsor studies likely to produce unfavourable results. This observation suggests that a more rigorous examination of the relationship between sponsorship and nutrition research might be likely to arrive at conclusions similar to those derived from drug and tobacco sponsorship studies.

\section{Partnerships and alliances}

Many nutrition societies actively seek food industry support of educational, research, and service projects. All parties engaged in such alliances justify them in terms of a common goal - to improve the health of the public. All maintain that the relationships do not compromise their views on nutrition issues. The following examples, however, suggest that some questioning of this assumption may be justified.

\section{American Heart Association: endorsements}

In 1988, the American Heart Association (AHA), a longtime distinguished champion of research and education promoting low-fat and other dietary approaches to prevention of coronary heart disease, embarked on a programme to label foods as 'heart-healthy'. The programme would identify foods that met certain standards for fat, saturated fat, cholesterol, and sodium with a logo consisting of a red heart with a white check mark and the words 'American Heart Association Tested \& Approved'. Initially, AHA planned to collect fees from companies making approved products - \$40000 for testing as well as an annual educational fee that ranged from $\$ 5000$ to $\$ 1$ million depending on the size of the company - and was expected to benefit from company advertising and promotion of the partnership ${ }^{27,28}$. The proposal immediately ran into opposition from United States Department of Agriculture (USDA) officials concerned that identifying single foods as heart-healthy distorted the nutritional principle that dietary patterns not single foods - are associated with disease prevention, and officials of the Food and Drug Administration (FDA) charged that the programme might interfere with the agency's efforts to develop new labelling rules ${ }^{29}$. Nevertheless, AHA invited 2300 makers of margarines, crackers, and frozen foods to apply for endorsement.

The first 'HeartCheck' foods appeared on shelves in early 1990, but representatives of seven states ${ }^{30}$ and two leading nutrition societies wrote to the FDA opposing the programme on the grounds that promoting the health benefits of single foods was misleading ${ }^{31}$. When nearly two-thirds of the companies that had joined the programme withdrew from participation, the AHA ended the programme and agreed to return the fees it had collected $^{32}$. In 1994, however, it tried a slightly different approach. This time, companies were to pay an initial fee of $\$ 2500$ and an annual renewal fee of $\$ 650$ for a seal of approval. By October 1997, 55 companies were participating, with 643 products certified ${ }^{33}$. For example, more than 50 Kellogg's products carried the AHA seal of approval. The company advertised that it was pleased to provide consumers with 'guidance on selecting hearthealthy foods', among which were such unlikely items as high-sugar Frosted Flakes, Fruity Marshmallow Krispies, and Low-Fat Pop-Tarts ${ }^{34}$. The current programme requires a $\$ 7500$ fee per product and $\$ 4500$ for annual renewals, with a discount if more than 25 products are submitted in one year. Because the rules preclude endorsement of medical foods, dietary supplements, alcoholic beverages, and products owned by tobacco companies $^{35}$, Kellogg's Cocoa Frosted Flakes is 'heart smart', but the equivalent cereal from Post (owned by Philip Morris) is $\operatorname{not}^{36}$. The programme also permits advertisements extolling 'cholesterol free, fat free' Florida Grapefruit Juice as a means to fight heart disease ${ }^{37}$. This 
approach can hardly help the public understand that healthful dietary patterns do not depend on just one food.

American Dietetic Association: sponsored activities The American Dietetic Association (ADA) represents the interests of about 70000 nutritionists holding credentials as Registered Dietitians. Food companies employ many of its members, and its relations with the industry are especially close. ADA acknowledged donations of $\$ 735000$ from groups and individuals contributing $\$ 10000$ or more during the 1998-1999 fiscal year, among which were 22 food product and trade associations. Overall, nearly 8\% of the Association's \$25 million annual income came from such grants that year. Reliance on such funding encourages perceptions that sponsorship prevents the ADA from ever criticising the food industry ${ }^{38}$.

Indeed, ADA's stance on dietary advice is firmly proindustry. Its basic tenets are that all foods contribute to healthful diets, and that no food should be considered good or bad ${ }^{39}$. In 1993, the Association collaborated with McDonald's on a campaign built around Happy Meals and toy food characters representing the major food groups ${ }^{40}$, and its journal routinely carries a page of government nutrition news compiled by The Sugar Association.

The blurring of the distinction between food company marketing and dietary advice is most evident in the ADA's 70 or so information Fact Sheets - each with its own corporate sponsor ${ }^{41}$. Table 1 presents examples of Fact Sheet topics, their sponsors, and typical statements. If the statements appear to have been written by the companies' public relations departments, it is no coincidence. Although the ADA retains final editorial control, corporate sponsors or public relations agencies draft the content ${ }^{42}$. In 2000, the ADA journal included a Kellogg's-sponsored Fact Sheet on vitamins during pregnancy, 'B smart for your heart and pregnancy with folic acid and vitamins B6 and B12'. Placed directly opposite was an advertisement for Kellogg's cereals, 'Have you heard the good news? Now many of your patients' favorite Kellogg's cereals are fortified with 100\% of the Daily Value of folic acid, B6 and B12, ${ }^{43}$. Because the FDA had not yet approved 'B smart for your heart' as a health claim, the sponsored Fact Sheet engaged the ADA - perhaps unwittingly - as a participant in Kellogg's 'back-door strategy' to evade FDA restrictions on label statements then in place ${ }^{44}$.

Such examples do not mean that the ADA ignores issues of conflicting interests. Indeed, its 1999 Code of Ethics includes a statement that 'the dietetic practitioner is alert to situations that might cause a conflict of interest or have the appearance of a conflict. The dietetics practitioner provides full disclosure when a real or potential conflict of interest arises ${ }^{45}$. One journal editorial on the code correctly pointed out that in the world of nutrition research, a conflict of interest does not necessarily exist just because scientists receive support from a food/drug company or a government agency as long as the interests of the various groups do not conflict ${ }^{46}$. Another argued that adequate safeguards exist in the form of codes of ethics and peer review ${ }^{47}$. Readers may well wonder, however, whether the Fact Sheets - or the ADA itself might express more critical views on some of the issues if they were independent of food company sponsorship.

\section{Disclosure and beyond}

The above examples were singled out for discussion not because they are necessarily more egregious than others, but because they more explicitly illustrate the potential conflicts of interests that can arise from sponsorship alliances. Given that food company sponsorship is not going to disappear, the question becomes one of

Table 1 Topics, sponsors, and representative statements in nutrition fact sheets issued by the American Dietetic Association, $1999-2000^{41}$

\begin{tabular}{|c|c|c|}
\hline Topic & Sponsor & Sample statement \\
\hline Agricultural biotechnology & Monsanto & $\begin{array}{l}\text { 'The US government has a well-coordinated system to } \\
\text { ensure that new agricultural biotechnology products are safe } \\
\text { for the environment and to animal and human health' }\end{array}$ \\
\hline Aspartame & NutraSweet & $\begin{array}{l}\text { 'Aspartame makes available a wide variety of food and } \\
\text { beverage choices for the person interested in maintaining a } \\
\text { healthful lifestyle' }\end{array}$ \\
\hline Canned foods & Steel Packaging Council & $\begin{array}{l}\text { 'Canned food is as nutritious as its fresh and frozen counterparts } \\
\text { upon preparation' }\end{array}$ \\
\hline Chocolate & Mars & $\begin{array}{l}\text { 'Chocolate is no longer a concern for those wary of saturated } \\
\text { fat, and...in fact, chocolate can be part of a heart-healthy eating } \\
\text { plan' }\end{array}$ \\
\hline Fats and Oils & $\begin{array}{l}\text { National Association of } \\
\text { Margarine Manufacturers }\end{array}$ & $\begin{array}{l}\text { 'Margarine products and liquid vegetable oil have little saturated } \\
\text { fat and contain no cholesterol' }\end{array}$ \\
\hline Olestra & Proctor \& Gamble & $\begin{array}{l}\text { 'Fat replacers like olestra are one of the many acceptable ways } \\
\text { to help reduce the amount of fat and calories in your diet' }\end{array}$ \\
\hline Snacking & Nabisco & $\begin{array}{l}\text { 'In today's busy world, snacking is part of our daily routine. We } \\
\text { enjoy milk and cookies after school... and reach for a handful of } \\
\text { crackers before bed' }\end{array}$ \\
\hline Sodium & Campbell Soup & $\begin{array}{l}\text { 'The link between the sodium you eat and high blood pressure } \\
\text { is unclear' }\end{array}$ \\
\hline
\end{tabular}


establishing principles and policies that preserve genuine and perceived independence. In my experience, professional soul-searching on this question has been rare. The last national debate that I can remember took place in 1980 when the Food and Nutrition Board of the National Academy of Sciences issued Toward Healthful Diets, a report that chided government agencies for the lack of 'sound scientific foundation' in their advice on dietary cholesterol $^{48}$. Contemporary critics noted that several members of the Board had research and consulting ties to egg trade associations ${ }^{49}$ and that the Board was supported by an industry committee that had paid for the report ${ }^{50}$. The Academy, embarrassed by these disclosures, eliminated the industry panel and restructured the Board to include new members with fewer ties to food companies $^{51,52}$. My impression is that it would be more difficult to find such people these days.

Today, most commentators - but by no means all maintain that the first step in protecting against conflicting interests is disclosure of financial relationships ${ }^{53}$. In the past, even when nutrition researchers were willing to disclose industry connections, they rarely were required to do so ${ }^{7}$. This situation is now changing. Since 1998, the FDA has asked members of its review committees to state whether they have received stock, consulting fees, or other financial support from companies with interests in the agency's regulatory decisions ${ }^{54}$, a requirement that many consider long overdue ${ }^{55}$. Leading science and medicine journals have begun to require financial disclosure statements from authors ${ }^{19}$. The Lancet, for example, tells authors that 'the conflict of interest test is a simple one...Is there anything...that would embarrass you if it were to emerge after publication and you had not declared it? The Editor needs to be informed ${ }^{56}$. Nutrition publications such as the Journal of the American Dietetic Association, Journal of Nutrition, and Nutrition in Clinical Care have also instituted disclosure statements.

The requirements of the British Medical Journal set a gold standard. As summarised in Appendix B, this journal requires authors to submit an elaborate checklist in the hope that it will increase the number of authors who disclose competing interests' ${ }^{57}$. The editor's concern was that authors often did not disclose financial ties. Indeed, research indicates that although many authors hold conflicting interests, few editors require disclosure and few authors disclose. Studies have found that $70 \%$ of articles from journals with disclosure policies fail to mention conflicts of interest ${ }^{19}$. Among nearly 1400 leading scientific and biomedical journals surveyed in 1997, only $16 \%$ had disclosure policies, and less than $1 \%$ of their articles disclosed financial relationships. The authors attribute the low rates to poor compliance ${ }^{58}$. Despite such findings, most researchers view themselves as incorruptible and do not believe that industry support could affect their views ${ }^{7}$.
Some commentators dismiss suggestions of influence as 'without evidence or merit"59, or argue that disclosure requirements are inherently irrational, lead to censorship, and so unfairly taint good work as to constitute 'scientific McCarthyism, ${ }^{60}$. Despite such accusations, the one study to examine how journal editors act on disclosure of financial conflicts found a majority $(60 \%)$ never to have rejected a paper for that reason. Only 19\% had rejected papers on that ground alone, and another 20\% had done so in conjunction with other (unspecified) factors ${ }^{58}$.

A British paediatric society, wrenched by controversy over sponsorship by infant formula companies, has developed guidelines that extend beyond disclosure. The society bases its policy on the premise that the products themselves are neither ethical nor unethical, but the ways they are used, produced, or marketed can raise ethical issues. Thus, it chooses to refuse sponsorship from makers of guns or tobacco; to be cautious about alcohol, soft drinks, junk foods, and infant formulas; but to be willing to accept sponsorship from companies that make pharmaceutical products, medical equipment, or mineral water (Appendix C) ${ }^{61}$. Whether such guidelines will address underlying concerns remains to be seen ${ }^{19}$.

Should researchers, practitioners, professional societies, and academic departments 'just say no' to corporate funding ${ }^{62}$ ? It is unrealistic to think that doing so will become common practice, not least because of the evident benefits of such arrangements. Given current funding realities, the most useful approach may be to balance risks and benefits on a case-by-case basis. Most colleges and universities in the USA now require faculties to file annual 'conflict of interest' statements, in which financial relationships must be disclosed ${ }^{63}$. In 2001, the US Department of Health and Human Services issued guidance to clinical investigators about how to handle financial relationships with companies. Noting that there is little agreement on what is right or wrong in these situations, the agency recommended that institutions form committees with independent members outside the institution, collect information on financial relationships, conduct educational programmes, review agreements made by individual investigators, and manage their own conflicts of interest ${ }^{64}$. Although compliance may continue to pose problems, these suggestions encourage attention to the issues and deserve to be taken seriously.

Some nutritionists commentating on the topic believe that industry contributions in the form of travel, meals, honoraria, and conference sessions pose minimal conflict, but that ethical issues become more acute when companies contribute toward specific academic and professional programmes ${ }^{65}$. Others argue that the public assumes that non-profit professional associations provide unbiased, objective information about diet and health, and that sponsorship implies product endorsement. The goals of nutrition professionals and food companies are not necessarily the same and conflicting interests in 
industry partnerships are always a possibility ${ }^{66}$. In an ideal world, no nutritionist would need to take food industry funding. Given current realities, the challenge is to recognise the potential conflicts that may arise, take steps to minimise them, and keep public health at the forefront of professional actions and opinions.

\section{Disclosure}

New York University pays my salary in full. I occasionally consult for food companies and often speak at sponsored conferences (otherwise I would be speaking only to myself). My personal policy - imperfect as it may be - is to accept reimbursement from sponsors for travel, hotel, and meals. I do not accept honoraria or consulting fees from food companies, however, but ask that they donate the funds to my department's student scholarship account. My answers to the additional questions in Appendix B are all 'no'11.

\section{Acknowledgements}

The author thanks Amy Bentley, JoAnn Silverstein, and Sam Silverstein for critical comments on an earlier draft of this paper, and Monica Bhagwan, Stacey Freis, and Suzanne Rostler for research assistance.

\section{References}

1 Kluger R. Ashes to Ashes: America's Hundred-Year Cigarette War, the Public Health, and the Unabashed Triumph of Philip Morris. New York: Alfred A. Knopf, 1996.

2 Barnes DE, Bero LA. Why review articles on the health effects of passive smoking reach different conclusions. JAMA 1998; 279: 1566-70.

3 Cho MK, Bero LA. The quality of drug studies published in symposium proceedings. Ann. Intern. Med. 1996; 124: 485-9.

4 Soley LC. Leasing the Ivory Tower: The Corporate Takeover of Academia. Boston, MA: South End Press, 1995.

5 Relman AS. Separating continuing medical education from pharmaceutical marketing. JAMA 2001; 285: 2009-12.

6 Moses H, Martin JB. Academic relationships with industry: a new model for biomedical research. JAMA 2001; 285 : $933-5$.

7 Rosenthal B, Jacobson M, Bohm M. Feeding at the company trough. Congressional Record, August 26, 1976; H8974-7.

8 Cannon G. The Politics of Food. London: Century Hutchinson, 1987.

9 Dietary Guidelines Alliance. Reaching Consumers with Meaningful Health Messages: A Handbook for Nutrition and Food Communicators. Chicago, IL: Dietary Guidelines Alliance, 1996.

10 Owen BM, Braeutigam R. The Regulation Game: Strategic Use of the Administrative Process. Cambridge, MA: Ballinger, 1978; 7 .

11 Nestle M. Food Politics: How the Food Industry Influences Nutrition and Health. Berkeley, CA: University of California Press, 2002 (in press).
12 Shell ER. The Hippocratic wars. New York Times Magazine, June 28, 1998; 34-8.

13 American Dietetic Association and American Dietetic Association Foundation. 1999 ADA/F Annual Report [Online]. Available: http://www.eatright.org/ (2000, 13 Apr).

14 Angell M. Is academic medicine for sale? N. Engl. J. Med. 2000; 342: 1516-8

15 Altman LK. New England Journal of Medicine names third editor in a year. New York Times, May 12, 2000; A20.

16 Wazana A. Physicians and the pharmaceutical industry: is a gift ever just a gift? JAMA 2000; 283: 373-80.

17 Wilde P. Media coverage spurs fad for vitamin pills, after year-long industry effort. Nutrition Week, May 22, 1992; 1-6.

18 Blumenthal D, Campbell EG, Causino N, Louis KS. Participation of life-science faculty in research relationships with industry. N. Engl. J. Med. 1996; 335: 1734-9.

19 Krimsky S, Rothenberg LS, Kyle G, Stott P. Financial interests of authors in scientific journals: a pilot study of 14 publications. Sci. Eng. Ethics 1996; 2: 395-410.

20 Stelfox HT, Chua G, O'Rourke K, Detsky AS. Conflict of interest in the debate over calcium-channel antagonists. $N$. Engl. J. Med. 1998; 338: 101-6.

21 Bero LA. Accepting commercial sponsorship: disclosure helps - but is not a panacea. Brit. Med. J. 1999; 319: 653-4.

22 Friedberg M, Saffran B, Stinson TJ, Nelson W, Bennett CL. Evaluation of conflict of interest in economic analyses of new drugs used in oncology. JAMA 1999; 282: 1453-7.

23 Bero LA, Barnes D. Industry affiliations and scientific conclusions [letter]. JAMA 1998; 280: 1142.

24 Avoid financial 'correctness': insistence that authors declare business interests in papers is beside the point [editorial]. Nature 1997; 385: 469.

25 Campbell P, Dhand R. Nature insight: obesity. Nature 2000; 404: 631-77.

26 Bray GA, Tartaglia LA. Medicinal strategies in the treatment of obesity. Nature 2000; 404: 672-7.

27 Squires S. Food and choice: Heart Association's plan to endorse certain products is a bold gamble in educating a confused public. Washington Post Health, July 5, 1988; 9

28 Sugarman C. What price approval? Heart Association's plan raises food firms' pressure. Washington Post, August 30, 1989; E1, E4.

29 Parachini A. Food fight: Heart Association plan to label 'healthy' foods drawing fire from agencies, nutritionists. Washington Post, August 2, 1988; E1, E6.

30 State attorneys general support FDA position on AHA HeartGuide label. Nutrition Week, February 8, 1990; 1.

31 American Institute of Nutrition and The American Society for Clinical Nutrition. Objections to 'Seal of Approval Programs'. Am. J. Clin. Nutr. 1990; 51(4): unpaginated.

32 Angier N. Heart Association cancels its program to rate foods. New York Times, April 3, 1990; A1, C6.

33 American Heart Association. Food for thought [flier]. October, 1997.

34 Kellogg Company. Letter in press release addressed to Dear Health Professional. Battle Creek, MI, February, 1997.

35 American Heart Association. Food certification program [Online]. Available: http://americanheart.org/ (2000, 15 Apr).

36 Raeburn P. The Heart Association is selling its soul. Business Week, November 24, 1997; 96.

37 Florida Grapefruit Juice. Fight heart disease; drink Florida Grapefruit Juice [advertisement]. New York Times, October 29, 1997; F4.

38 Burros M. Additives in advice on food. New York Times, November 15, 1995; C1, C5. 
39 American Dietetic Association. Position of the American Dietetic Association: nutrition education for the public. J. Am. Diet. Assoc. 1996; 96: 1183-7.

40 McDonald's Corporation. American Dietetic Association and McDonald's partner to teach kids the fundamentals of nutrition [news release]. Oak Brook, IL, February 24, 1993.

41 American Dietetic Association. Nutrition Fact Sheets [Online]. Available: http://www.eatright.org/ (1997, November 15; 2000, April 10).

42 Gallagher A. Taking a stand on emerging issues. J. Am. Diet. Assoc. 2000; 100: 410.

43 Kellogg's full-page colour advertisement. J. Am. Diet. Assoc. 2000; 100: 496.

44 Kellogg's claim for heart benefits challenged by CSPI. Food Regulation Weekly, July 3, 2000; 10.

45 American Dietetic Association. Code of ethics for the profession of dietetics. J. Am. Diet. Assoc. 1999; 99: 109-13.

46 McNutt K. Conflict of interest. J. Am. Diet. Assoc. 1999; 99 29-30.

47 Rock CL. Conflict of interest: an import issue in nutrition research and communications. J. Am. Diet. Assoc. 1999; 99 31-2.

48 Food and Nutrition Board. Toward Healthful Diets. Washington, DC: National Academy of Sciences, 1980.

49 Brody JE. Experts assail report declaring curb on cholesterol isn't needed. New York Times, June 1, 1980; A1.

50 Broad WJ. Academy says curb on cholesterol not needed. Science 1980; 208: 1354-5.

51 Wade N. Food Board's fat report hits fire. Science 1980; 209: 248-9.

52 National Academy of Sciences tightens its grip on the Food and Nutrition Board. Nutrition Today, January/February 1984; 31-2.

53 Krimsky S, Rothenberg LS. Financial interest and its disclosure in scientific publications. JAMA 1998; 280 225-6.

54 Food and Drug Administration. Final guidance on industry-supported scientific and educational activities: notice. Federal Register; 62: 64074-100 (December 3, 1997).

55 Stolberg SG. New rules will force doctors to disclose ties to drug industry. New York Times, February 3, 1998; A12.

56 The Lancet. Writing for The Lancet [Online]. Available: http://www.thelancet.com/ (2000, 10 Apr).

57 British Medical Journal. Declaration of competing interest: guidance for authors [Online]. Available: http:// www.bmj.com/guides (1999, 17 Jul).

58 Krimsky S, Rothenberg LS. Conflict of interest policies in science and medical journals: editorial practices and author disclosures. Sci. Eng. Ethics 2001; 7: 205-18.

59 Meydani SN, Meydani M, Leka L, Blumberg J. Vitamin E supplementation and immune response in elderly patients [letter]. JAMA 1998; 279: 505-6.

60 Rothman KJ. Conflict of interest: the new McCarthyism in science. JAMA 1993; 269: 2782-4.

61 Royal College of Paediatrics and Child Health. Commercial sponsorship in the Royal College of Paediatrics and Child Health. London: Royal College of Paediatrics and Child Health, 1999.

62 Kassirer JP. Financial indigestion. JAMA 2000; 284: 2156-7.

63 Bero LA. Disclosure policies for gifts from industry to academic faculty. JAMA 1998; 279: 1031.

64 US Department of Health and Human Services. Financial relationships in clinical research: issues for institutions, clinical investigators, and IRBs to consider when dealing with issues of financial interests and buman subject protection [Online]. Available: http://ohrp.osophs.dhhs. gov/ (2001, 11 Apr).

65 Tobin DS, Dwyer J, Gussow JD. Cooperative relationships between professional societies and the food industry: opportunities or problems? Nutr. Rev. 1992; 50: 300-306.

66 Levine J, Gussow JD. Consider the source. New York Times, September 30, 1994; A31.

\section{Appendix A: Quotations from research studies, reviews, or editorials supported fully or in part by food, beverage, or supplement companies}

There is reason to be concerned that lowering NaCl intake may have long-term metabolic risks that have not been fully identified... we do not have solid evidence that lower $\mathrm{NaCl}$ intake prospectively will prevent or control high blood pressure (the European Committee for the Study of Salt and the US Salt Institute paid publication costs) ${ }^{\mathrm{a}}$.

Zinc gluconate...significantly reduced the duration of symptoms of the common cold by $40 \%$ compared with placebo $^{\mathrm{b}}$ (one author reportedly earned nearly \$145000 from sale of stock in the product prior to publication of the paper) ${ }^{\mathrm{C}}$.

The possible risk of pulmonary bypertension associated with dexfenfluramine is small and appears to be outweighed by benefits when the drug is used appropriately ${ }^{\mathrm{d}}$ (both authors had consulted for the drug's manufacturer) ${ }^{\mathrm{e}}$.

High-fibre breakfast cereals may belp to reduce risk of cancers that are associated with poor fibre intakes (the author is employed by Kellogg's, UK) ${ }^{\mathrm{f}}$.

The prepared meal plan is a simple and effective strategy for improving dietary compliance and CVD endpoints (Campbell Soup supplied the meals and funded the study) $)^{\mathrm{g}}$.

Substantial evidence indicates that intakes greater than the recommended dietary allowances (RDAs) of...calcium, folic acid, vitamin E, selenium, and chromium reduce the risk of certain diseases for some people (the author is an official of a supplement-industry trade association $)^{\mathrm{h}}$.

Scientific findings indicate that the prevalence of lactose intolerance is grossly overestimated (one author works for the National Dairy Council) ${ }^{\mathrm{i}}$.

A moderate intake of wine (2-5 glasses per day) was associated with a 24-31\% reduction in all-cause mortality (the French Technical Institute of Wine helped fund the study) ${ }^{j}$.

[F]or most patients, an LDL-lowering drug will be required to achieve an $L D L$ cholesterol level of $<100 \mathrm{mg} / \mathrm{dL}$ (the Chair and five of 13 Panel members reported receiving honoraria, consulting fees, or grants from up to 10 pharmaceutical companies making cholesterol-lowering drugs ${ }^{\mathrm{k}}$.

Frequent egg consumption does not appear to adversely affect serum cholesterol concentrations (study supported by the Egg Nutrition Center) ${ }^{1}$.

Studies show soft drink consumption by school-aged 
children is not linked to obesity, poor diet quality, or lack of exercise (supported by the National Soft Drink Association $)^{\mathrm{m}}$.

\section{Notes to Appendix A}

${ }^{a}$ Muntzel M, Drüeke T. A comprehensive review of the salt and blood pressure relationship. Am. J. Hypertension 1992; 5: 1s-42s.

${ }^{\mathrm{b}}$ Mossad SB, Macknin ML, Medendorp SV, Mason P. Zinc gluconate lozenges for treating the common cold: a randomized double-blind, placebo-controlled study. Ann. Intern. Med. 1996; 125: 81-8.

${ }^{\mathrm{c}}$ Hilts PJ. Researcher made profit after study: invested in maker of cold treatment. New York Times, February 1, 1997; 6.

dManson JE, Faich GA. Pharmacotherapy for obesity - do the benefits outweigh the risks? [editorial]. N. Engl. J. Med. 1996; 335: 659-60.

${ }^{\mathrm{e}}$ Hilts PJ. Mix-up seen in backing obesity drug. New York Times, August 29, 1996; D18.

f O'Sullivan KR. Starting the day right! In: Smith G, ed. Children's Food: Marketing and Innovation. London: Blackie Academic \& Professional, 1997.

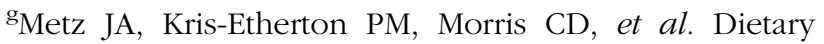
compliance and cardiovascular risk reduction with a prepared meal plan compared with a self-selected diet. Am. J. Clin. Nutr. 1997; 66: 373-85.

${ }^{\mathrm{h}}$ Hathcock JN. Vitamins and minerals: efficacy and safety. Am. J. Clin. Nutr. 1997; 66: 427-37.

${ }^{\mathrm{i}}$ McBean LD, Miller GD. Allaying fears and fantasies about lactose intolerance. J. Am. Diet. Assoc. 1998; 98: 671-6.

'ंRenaud SC, Guéguen R, Schenker J, d'Houtaud A. Alcohol and mortality in middle-aged men from Eastern France. Epidemiology 1998; 9: 184-8.

${ }^{\mathrm{k}}$ Expert Panel. Executive Summary of the Third Report of the National Cholesterol Education Program (NCEP) Expert Panel on Detection, Evaluation, and Treatment of High Blood Cholesterol in Adults (Adult Treatment Panel III). JAMA 2001; 285: 2486-97.

${ }^{1}$ Kerver JM, Bianchi LJ, McNamara DJ, Song WO. Frequent egg consumption is not related to elevated serum cholesterol in the US population. J. Am. Diet. Assoc. 2000; 100(9): A-61.

${ }^{\mathrm{m}}$ Nedelman J. EB [Experimental Biology] 2001 press release. Washington, DC: Georgetown University Center for Food and Nutrition Policy, April 3, 2001.

\section{Appendix B: Selected elements of British Medical Journal guidance for authors on 'competing' interests $^{57}$}

During the past five years, have you:

A. Accepted the following from an organisation that may in any way gain or lose financially from your study or opinion:

- Reimbursement for attending a symposium?

- A fee for speaking?

- Funds for research?

- Fees for consulting?

B. Been employed by - or held stocks or shares in - an organisation that may gain or lose financially from your study or opinion.

C. Held any other competing interests that might prove embarrassing if discovered after publication, such as:

- A close relationship with, a strong antipathy to, or an academic link or rivalry to a person whose interests may be affected by publication of your paper.

- Membership in a political party or special interest group whose interests might be affected by publication of your paper.

- A deep personal or religious conviction that may have affected what you wrote and that readers should be aware of when reading your paper.

\section{Appendix C: Recommendations of the Royal College of Paediatrics and Child Health (London) on accepting commercial sponsorship: selected examples $^{61}$}

Sponsorship of Societies:

- Should not be accepted from companies that produce tobacco or firearms or exploit children.

- Should only be accepted from companies that can demonstrate unequivocally that their conduct does not breach any relevant code or practice.

- Should be fully and transparently disclosed.

Sponsorship of Individuals:

- Must not be lavish; the guiding principle should be whether individuals would be willing to have these arrangements generally known.

- May be accepted when convinced that doing so will benefit work without doing harm.

- Must be under the full control of the investigator. 